\title{
The Effect of Combination Therapy of A Warm Ginger Stew Compress and Ki. 3 Point Acupressure on the Pain Level of Gout Arthritis Patients in Indonesia
}

\author{
Enji Meilia Era Pertiwi ${ }^{1}$, Sidik Awaludin ${ }^{2}$ and Annas Sumeru ${ }^{2}$ \\ ${ }^{1}$ Student of School of Nursing, Faculty of Health Science, Jendral Soedirman University, Purwokerto, Indonesia \\ ${ }^{2}$ Lecturer of School of Nursing, Faculty of Health Science, Jendral Soedirman University, Purwokerto, Indonesia
}

\section{ABSTRACT}

Introduction: Gout arthritis is a systemic disease caused by deposition of monosodium urate crystals in the joints, causing pain. Pain management may include complementary therapy such as combination therapy of a warm ginger stew compress and Ki. 3 point acupressure to reduce pain. This research aimed to examine the effect of combination therapy of a warm ginger stew compress and Ki. 3 point acupressure on the pain level of gout arthritis patients.

Methods: The research design for this study is a quasi-experiment pre-test and post-test, with a control group design for 30 respondents. The respondents were assigned to an experimental group with combination therapy of a warm ginger stew compress and Ki. 3 point acupressure for about 30 minutes, and a control group with a warm ginger stew compress for about 15 minutes. Each group consisted of 15 people. The data was analysed using a paired t-test, independent t-test, and Mann Whitney test.

Results: The Mann Whitney test showed an average decrease of pain level in the experimental group of 1,7333 and the control group of 1,0667 so, there were differences in the decreased of pain level before and after intervention between the two groups with $p$-value $=0.013$.

Conclusion: Combination therapy of a warm ginger stew compress and Ki. 3 point acupressure were effective in decreasing the pain level of gout arthritis patients in Puskesmas 1 Purwokerto Timur. This therapy can be used for the gout arthritis patient to reduce pain level.

\section{ARTICLE HISTORY}

Received: February 25, 2019

Accepted: December 23, 2019

\section{KEYWORDS}

acupressure; ginger compress; gout arthritis

\section{CONTACT}

\section{Annas Sumeru}

$\triangle$ schumeru@gmail.com

$\doteq$ Faculty of Health Science, Jendral Soedirman University, Purwokerto, Indonesia

Cite this as: Pertiwi, E. M. E., Awaludin, S., \& Sumeru, A. (2019). The Effect of Combination Therapy of A Warm Ginger Stew Compress and Ki. 3 Point Acupressure on the Pain Level of Gout Arthritis Patients in Indonesia. Jurnal Ners, 14(2), 152-155. doi:http://dx.doi.org/10.20473/jn.v14i2.9199

\section{INTRODUCTION}

Gout arthritis is a disease of the joints due to a metabolic disorder of uric acid that accumulates (hyperuricemia) in the body tissues (Sustrani, Nature, \& Hadibroto, 2007). Gout arthritis occurs due to the deposition of monosodium nerves in the joints. The deposition of monosodium fibres (tophi) will cause inflammation. The prevalence of gout arthritis is expected to continue to increase.

The prevalence of asymptomatic hyperuricemia in the general population in the USA is about $2-13 \%$. Based on the results of basic health research by Riskesdas (2013), joint disease is currently the third $(24.7 \%)$ leading disease that is not contagious after stroke (57.9\%) and hypertension (36.8\%), which increases as a person gets older. The prevalence of gout arthritis in Bandungan, Central Java, as reported by the collaborative research of the World Health Organization International League of Associations for Rheumatology Community Oriented Program for Control of Rheumatic Disease (WHOILAR COPCORD) among 4,683 people aged 15-45 years, was $17.6 \%$ incidence of gout arthritis, experienced by men at $24.3 \%$ and women at $11.7 \%$ (Kurniari, 2011). The results of a survey conducted in Clinics 1 Purwokerto Timur, for 10 months (January-October 2017) found as many as 33 patients with hyperuricemia. The survey results showed severe pain $(28.60 \%)$, moderate pain $(42.85 \%)$, and mild pain $(28,5 \%)$ of the joint. The definition of pain, according to the International Association for the Study of Pain (IASP) is "as subjective knowledge and an unpleasant emotional experience associated with actual tissue damage or potential or perceived in the events which occurred 
the damage" (IASP in Potter \& Perry, 2005). Pain that is not immediately handled could lead to discomfort, broad limitations in joint motion, distractions, and other activities of daily living (Handono \& Richard, 2013). These impacts indicate that efforts need to be made to control the pain.

It may be managed by pharmacological and nonpharmacological pain therapy. Pharmacological therapy is often used to reduce joint pain, for example by non-steroidal anti-inflammatory drugs (NSAIDs) to control inflammation, which has a bitter taste (Gliozzi, Malara, Muscoli, \& Mollace, 2016). There are some side effects from consuming these drugs such as nausea, vomiting, kidney failure, and even death if it is taken without proper instruction in the long term (Misnadiarly, 2008). Nonpharmacological therapy can be used as a complementary therapy, which is effective and safe, for example the use of warm ginger stew compress therapy and acupressure.

The warm ginger stew compress is a warm compress combined with ginger that contains oleoresin, where there is substance in the oleoresin gingerol. Gingerol serves as a compound that is not volatile. Gingerol induces pharmacological and physiological effects of antioxidants that could inhibit prostaglandins and cyclooxygenase which may reduce pain (Nahed \& Tavakkoli, 2015). In addition to the warm ginger stew compress, there are other therapies that can be used to handle pain, for example acupressure. The acupressure massage techniques through stimulation of acupressure points will enable the modulation of pain in opioid systems, non-opioid systems, and inhibition on sympathetic dystrophy to reduce nerve pain.

In view of the benefit of warm ginger stew and acupressure to control pain rather than using only single method, this research was conducted to identify the effect of combination therapy of compress of the decoction of warm ginger and acupressure point Ki. 3 on the level of pain among patients suffering from gout arthritis at clinics in region I of Purwokerto Timur.

\section{MATERIALS AND METHODS}

This research used a quasi-experimental research design with pretest and posttest, with a control group design. The data was collected from March to April 2018 in the region and Arcawinangun, Mersi Purwokerto. The sample in this study is 30 respondents, where the respondents are patients from clinics I Purwokerto Timur. The respondents were divided into experiments group with the combination therapy intervention compresses of warm ginger stew and acupressure point Ki. 3 for 30 minutes and the control group with intervention therapy of warm ginger stew compress for 15 minutes. Each arm of the of the intervention and control group had 15 respondents. The therapy was conducted by the researcher. The Standard of Operational Procedure can be seen in the supplemental file of this manuscript. Nonprobability sampling techniques of convenience sampling were used to recruit participants. The research was of the variable of a combination of warm ginger stew compress therapy and acupressure point Ki. 3 against gout arthritis pain scale. The research instrument used was a numerical scale on the observation sheet. Data were analysed using the Mann Whitney bivariate test.

\section{RESULTS}

Table 1. shows the majority of respondents in this study were aged $>60$ years and the majority of uric acid levels of respondents were $>8.5 \mathrm{mg} / \mathrm{dl}$. Both groups showed a p-value of $>0.05$ meaning they are homogenous using the Shapiro Wilk test.

Table 2. indicates respondents of this research according to the gender of the majority of women, at 26 respondents (86.7\%), and according to the majority who do not work totalled 17 respondents (56.7\%). Characteristics of respondents according to the gender and employment shows a p-value of 0.05 $>$ meaning in both groups they are homogeneous using the Chi Square test.

Table 3. shows that the test based on the paired $t$ test experimental group and the control group had a $\mathrm{p}$-value of 0.001 . Both the experimental group and the control group pain levels were decreased. However, it indicates that there is no difference in the scale of pain in experimental and control groups. After that, a Mann Whitney test was done to see the difference in decreased pain of both groups.

Table 1. Respondent characteristics based on age and blood urea levels $(n=30)$

\begin{tabular}{lccccc}
\hline \multirow{2}{*}{ Characteristic } & \multicolumn{2}{c}{$\begin{array}{c}\text { Experiment } \\
\text { group }\end{array}$} & \multicolumn{2}{c}{$\begin{array}{c}\text { Control } \\
\text { group }\end{array}$} & \multirow{2}{*}{$\boldsymbol{p}$} \\
\cline { 2 - 5 } & Mean & SD & Mean & SD & \\
\hline Age & 64,5 & 8,4 & 61,6 & 9,5 & 0,847 \\
$\begin{array}{l}\text { Blood urea } \\
\text { levels }\end{array}$ & 8,7 & 2,3 & 8,6 & 1,8 & 0,620 \\
\hline
\end{tabular}

Table 2. Respondents' characteristics according to gender and jobs $(n=30)$

\begin{tabular}{lccccc}
\hline \multirow{2}{*}{ Characteristic } & \multicolumn{2}{c}{ Experiment } & \multicolumn{2}{c}{ Control } & \multirow{2}{*}{$\boldsymbol{p}$} \\
\cline { 2 - 4 } & $\mathbf{n}$ & $\mathbf{\%}$ & $\mathbf{n}$ & $\mathbf{\%}$ & \\
\hline Gender & 2 & 13,3 & 2 & 13,3 & 1,00 \\
$\quad$ Man & 13 & 86,7 & 13 & 86,7 & 0 \\
Women & & & & & \\
Jobs & 8 & 53,3 & 9 & 60 & 0,71 \\
$\quad$ Do not work & 7 & 46,7 & 6 & 40 & 3 \\
Work & & & & &
\end{tabular}


The table 4 test results showed Mann Whitney pvalue $=0,013(p$-value of $0.05<)$ which means that there is a difference in the level of pain between the two groups after the intervention. Those results were reinforced with a mean decrease in pain in the experimental group, i.e. 1.7333 and in the control group 1.0667.

\section{DISCUSSION}

The majority of respondents from this study were aged 60 years and above. The average age of respondents for intervention and control groups were respectively $64,47 \pm 8,391$ year and $61,60 \pm$ 2,467 years. This is in line with the research by Untari (2017) that shows the majority $(85.71 \%$, $\mathrm{n}=12)$ of respondent are women $(86.7 \%, \mathrm{n}=26)$. This is in accordance with the research by Untari (2017) that shows that the majority $(71.4 \%, n=10)$ of respondents experiencing gout arthritis older woman is aggregating. This is good for further research to know the differences of pain level between men or women who suffer from gout arthritis.

Hermawati \& Probosari (2015) showed that the majority of the respondents were women age 60years-old and above. The relationship of age increased with levels of uric acid due to the presence of the aging process resulting in decreased organ functions in the body, such as kidney filtration speed, excretion, and reabsorption against the metabolism of uric acid. Increased levels of uric acid in women occur due to the process of the menopause that results in decreased production of the hormone oestrogen. The hormone oestrogen serves as an uricosuria agent that helps the expulsion of uric acid via the kidneys (Setyoningsih, 2009). Meiyetriani, Hamza, \& five (2016) explained that during puberty males have higher uric acid levels, whereas women will have an increase in uric acid level when approaching menopause due to oestrogen uricosuria.

The uric acid levels of respondents showed a mean of uric acid levels of respondents of $8.720 \pm$ $2.2693 \mathrm{mg} / \mathrm{dl}$ in the experimental group and 8.633 $\pm 1.7971 \mathrm{mg} / \mathrm{dl}$ in the control group. Gout arthritis occurs due to the deposition of uric acid crystals in the joint tissues that affects the inflammatory reaction. The presence of uric acid crystals allows the interaction of the phospholipid membrane and the serum factors that contribute to the inflammatory reaction (Martillo et al, 2014).

The results showed most respondents did not work, at 17 respondents (56.7\%). This is in contrast to the research of Meiyetriani et al (2016) that showed the majority of arthritis gout experience was in those who were working, as much as $60 \%$ compared to not working as much as $11.7 \%$. Darmawan (2016) explains that less physical activity can cause metabolic syndrome which causes insulin resistance, leading to disorders of the excretion of uric acid. Insulin resistance causes the occurrence of
Table 3. Effect of The Scale of Pain Before and After The Intervention of The Experimental and Control Group ( $\mathrm{n}=30$ )

\begin{tabular}{lllll}
\hline Group & Variable & Mean & SD & $\boldsymbol{p}$ \\
\hline Experiment & $\begin{array}{l}\text { Pretest } \\
\text { Pain level }\end{array}$ & 6,5 & 1,8 & 0 \\
& $\begin{array}{l}\text { Posttest } \\
\text { Pain level }\end{array}$ & 4,8 & 1,5 & \\
Control & $\begin{array}{l}\text { Pretest Pain } \\
\text { level }\end{array}$ & 5,0 & 2,2 & 0 \\
& $\begin{array}{l}\text { Posttest Pain } \\
\text { level }\end{array}$ & 3,9 & 2,1 & \\
\hline
\end{tabular}

Table 4. The difference of pain scale decrease between experimental and control group $(n=30)$

\begin{tabular}{lcccc}
\hline \multicolumn{1}{c}{ Variable } & Group & Mean & SD & $\boldsymbol{p}$ \\
\hline $\begin{array}{l}\text { The } \\
\text { difference } \\
\text { pain scale of } \\
\begin{array}{l}\text { pre and post } \\
\text { intervention }\end{array}\end{array}$ & Control & 1,7 & 0,8 & \\
& & 1,1 & 0,7 & \\
\hline
\end{tabular}

oxidative phosphorylation disorders which will increase the concentration of adenosine systemic resistance, i.e. sodium, fibres, and water.

The results of the p-value show the experiment group and the control group equally mean the pain scale decreased. But based on the value of the mean, a significant decrease in pain occurred in the experimental groups. Based on the test results of the p-value, this shows that the experimental group and the control group equally mean that the pain scale decreased. But based on the value of the mean, a significant decrease in pain occurred in experimental groups, obtaining a combination therapy of warm ginger stew compress and acupressure point Ki. 3 than the control group who simply got the warm ginger stew compress therapy.

The average decrease in pain in the experimental group is significantly more than the control group. Chinomso \& Faluso's research (2014) stated that a combination of massage therapy and hot compresses against chest pain on chronic bronchitis patients effectively lowers the pain with a p-value $<0.001$. Lestari et al.'s (2014) qualitative research also states that the granting of a therapeutic massage and ginger compresses provide stimulation of the skin and the relaxing effect so effectively as to lower osteoarthritis pain. According to Hidayat \& Son (2016), ginger compresses effectively increase blood flow to get the analgesic and muscle relaxant effects of reducing inflammatory processes. This is confirmed by research from Dwi Putri et al. (2017) stating that the influence of giving a ginger compress against the intensity of the pain gout arthritis in the older people in the prosperous South Kalimantan PSTW Budi is more effective than with a warm 
compress, with $\mathrm{p}$-value $=0.000$. The research on acupressure points used is point Ki. 3. it works by giving local effects in the form of decreased pain on the area around the point of emphasis. It stimulates that the receptor stimulation activates a system of modulation of pain in the central nervous system that will stimulate the hormone endorphins to suppress transmission and perception of pain so that pain can be reduced (Majid \& Rini, 2016).

Research of combination therapy of warm ginger compresses stew and acupressure point Ki. 3 proved effective in lowering pain. This has been supported by previous studies which prove that the warm ginger stew compress therapy and acupressure can be used as a selection for non-pharmacological therapy for reducing pain in sufferers of gout arthritis.

\section{CONCLUSION}

The characteristics of respondents who experienced gout arthritis in the area of public health 1 Purwokerto Timur are mostly aged 60 years and above, with average levels of uric acid more than 8 $\mathrm{mg} / \mathrm{dl}$, most of them were female and not working. There is a significant difference in the scale of pain before and after intervention in the control group. The result from this study suggested that patients receiving combination therapy of warm ginger stew compresses and acupressure point Ki. 3 had reduced their pain level more than the group that were only given the warm ginger stew compress therapy.

\section{REFERENCES}

Chinomso U, N. \& Foluso O, O., 2014, Effectiveness of the combination of therapeutic chest massage and hot compress on chest pain among patients with chronic bronchitis: a nurse-led pilot study, International Journal of Scientific Research, 3(3): 236-238.

Darmawan, P. S., Kaligis, S. H. M., \& Assa, Y. A., 2016, Gambaran kadar asam urat darah pada pekerja kantor, Jurnal e-Biomedik, 4(2).

Dwi Putri, S., Q., Rahmayanti, D., \& Diani, N., 2017, Pengaruh pemberian kompres jahe terhadap intensitas nyeri gout artritis pada lasia di PSTW Budi Sejahtera Kalimantan Selatan, Dunia Keperawatan, 5(2): 90-95.

Gliozzi, M., Malara, N., Muscoli, S., \& Mollace, V., 2016, The treatment of hyperuricemia, International Journal of Cardiology, 213: 23-27.

Handono, S. \& Richard, S. D., 2013, Upaya menurunkan keluhan nyeri sendi lutut pada lansia di Posyandu Lansia Sejahtera, Jurnal Stikes, 6(1): 63-73.

Hermawati, E. \& Probosari, E., 2015, Hubungan asupan kafein dengan kadar asam urat di Puskesmas Banjarnegara, Journal of Nutrition College, 4(2): 480-485.

Hidayat, S. \& Putra, I. D. A., 2016, Pengaruh terapi kompres jahe terhadap tingkat nyeri osteoartritis pada lansia di UPT. Puskesmas Guluk-Guluk, Wiraraja Medika, 6(2): 53-59.

Kementerian Kesehatan Republik Indonesia, 2013, Riset Kesehatan Dasar. Diakses 7 November 2017 melalui http://www.depkes.go.id/resources/download/ general/Hasil\%20Riskesdas\%202013.pdf

Kurniari, P. K., Kambayana, G., \& Raka Putra, T., 2011, Hubungan hiperurisemia dan fraction uric acid clearance di Desa Tenganan Pegringsingan Karangasem Bali. Journal of internal medicine, 12(2).

Lestari, I., Nuryahati, Y., \& Setiyajati, A., 2014, Terapi kompres jahe dan massage pada osteoartritis di Panti Wreda St. Theresia Dharma Bhakti Kasih Surakarta, Skripsi, Stikes Kusuma Husada, Surakarta.

Majid, Y. A. \& Rini, P. S., 2016, Terapi akurpesur memberikan rasa tenang dan nyaman serta mampu menurunkan tekanan darah lansia, Jurnal Aisyah: Jurnal Ilmu Kesehatan, 1(1): 79-86.

Martillo, M. A., Nazzal, L., \& Crittenden, D. B., 2014, The Crystallization of monosodium urate, Current Rheumatology Reports, 16(2): 400.

Meiyetriani, E., Hamzah, \& Lima, F., 2018, Faktorfktor yang mempengaruhi kejadian asam urat di Kelurahan Pancuran Mas Depok Jawa Barat, AVERROUS, 3(2), 78-88.

Misnadiarly, 2008, Mengenal penyakit artritis, Puslitbang Biomedis dan Farmasi, Badan Litbangkes, 57.

Nahed, A., \& Tavakkoli, 2015, Ginger and its effect on inflammatory disease, Departement of Nutrition School of Public Health, 1(4).

Potter, P. A. \& Perry, A. G., 2005, Buku ajar fundamental keperawatan, ed. 4, vol. 1, EGC, Jakarta.

Saputra, K., 2004, Akupuntur klinik, Airlangga University Press, Surabaya.

Saputra, K., 2012, Buku ajar biofisika akupunktur dalam konsep kedokteran energi, Salemba Medika, Jakarta.

Setyoningsih, R., 2009, Faktor-faktor yang berhubungan dengan kejadian hiperurisemia pada pasien rawat jalan RSUP Dr. Kariadi Semarang, Skripsi, UNDIP, Semarang.

Singh, S. K., Patel, J. R., \& Bachle, D., 2014, A review on zingiber officinale: a natural gift, International Journal of Pharma and Bio Sciences, 5(3): 508525.

Sustrani, L., Alam, S., dan Hadibroto, I., 2007, Asam urat, Gramedia Pustaka Utama, Jakarta.

Untari, I., Sarifah, S., \& Sulastri, 2017, Hubungan antara penyakit gout dengan jenis kelamin dan umur pada lansia, URECOL, 267-272. 